\title{
CULTURAL AND LINGUISTIC DIMENSIONS IN TRANSLATION OF THE ECONOMIC TERMINOLOGIES
}

Dr. Mohammed Ali Hamoud Al- dyashi ${ }^{1}$

${ }^{1}$ N.I.A.S- Aden university - Yemen

Email: mohameddyashi5000@yahoo.com

${ }^{2}$ English Instructor, Ministry of Education-Yemen
Dr. Ali Ali Ahmed Motair ${ }^{2}$

HNSJ, 2021, 2(12); https://doi.org/10.53796/hnsj21213

Published at 01/12/2021

Accepted at 19/11/2021

\begin{abstract}
Economics is an important science because it is connected with other sciences like law, history, politics and other social sciences. This science deals with issues and topics that most people have anadequateknowledge about it. Many translators are interested in translating topics that are related to the economic field. The differences between Arabic and English language create problems for them. Therefore, the linguistic and cultural dimensions are one of such those problems, which affect the meaning and then the quality of translation. Many economic terminologies in the source language contain many different meanings. This issue means that the translator could experience difficulties in deciding how the translation will move towards the target reader. So, it isimportant for the translator to ask himself about the difficultieswhich lead to misunderstanding and ambiguity that may face him and his reader when they read his translation(Wilss, W. 1982). One of the biggest challenges for the translator is the whole cultural and linguistic elements in every terminology inside the text (Koller, W. 1997).
\end{abstract}

Key Words: Economics, Linguistic and cultural dimensions, Translation, Terminologies. 


\section{Introduction}

Translation can be defined as the ability to communicate by using the source language (SL) texts with available equivalence in the target language (TL). According to Nida and Taber (1982: 12), who point out that "translation consists of reproducing in the receptor language the closest natural equivalent of the source language message, firstly, in terms of meaning and secondly, in terms of style".In the process of producing translation, a lot of problems may be created, especially by the translator, who is Arabic language speaker; most of them are related to language and culture. For that reason, this article focuses on the linguistic and cultural dimensions of the economic terminology through adapting descriptive methodology using of some terminologies at this field. So, this article tries to shedlight on those linguistic and cultural dimensions through pointing out the role of these dimensions in clarifying the meaning of economic terminologies during translating process into Arabic language. In addition, the article will be proposing the remedies for the shortcomings in form of recommendation.

\section{Linguistic dimensions of the economic terminologies}

An economic language is a branch of English for Specific Purpose (ESP). It consists of two major lexical terminology types. These are called macroeconomic and microeconomic terminology. The economic terminologydeals with issues such as demand, supply, markets, firm, national income, unemployment and so forth. Many researchers try to translate topics in this field but they encounter problems during the process of the translation.

One of these problems are related to the element of culture and language. Therefore, culture is distinguished as one cause of the economic lexical problems inside language. The relationship between culture and translation is strong and durable as translation is an essential means through which people can get access to the cultures of other nations(Newmark, $\boldsymbol{P}$. 1991). In this sense, the translator should transfer concepts across two different cultures by using the linguistic systems of both languages (Krings, $\boldsymbol{P}$. 1986). Therefore, culture can be inherited or learned in both languages as it represents an interrelated network of different aspects of life. It acts as a bridge to understand the mutual meaning between the source term and the target one. Translators will have a huge responsibility, to act as mediators between two cultures. The ideal situation for any translator is to not only be bi-lingual but, also, bi-cultural. This feature will strengthen the translated material and lead to a sensible production. The knowledge of the source language (SL) culture will enable the translator to reconstruct the possible reactions of the source language (SL) recipient and their knowledge of the target language (TL) culture allows the translator to anticipate the possible reactions of the target language (TL) recipient.

We know that the field of economy is very vast. It can be considered as a vital 
component of our daily life dealing. This field has a specific term. This type of term connects with issues such as "inflation", "income", "unemployment" and so forth. So, there is a need to know more about translating the related expressions that are directly affected by cultural and linguistic inside this type of language. For example: monosemy in the economic language includes many terms, which give one acceptable literal translation. For example, "ceiling" is a term that gives the literal meaning in Arabic language as'سقف'[Saqf]. This economic term means amount of money that we cannot withdraw larger sum than it. Therefore, without the economic culture we cannot understand the meaning of such term. Moreover, Polysemy is in contrast to monosemy. It means the word that has more than one meaning. Polysemous words may cause difficulty for the translators as they may translate the common meaning and they ignore the other possible meanings. For example, "cachet" can be translated as'ختم ' . It, also, has other specific meaning in the economic field. Therefore, it can be translated into Arabic as' 'ضريبة إضافية [Driyba eâdfiya].Another polysemous word in the economics is the term "capital", which in common means 'money that used in the business but it has another specific meaning in the economics when it connects with other words. In this case, "capital goods" means "fundamental commodities" that cover words such as food and clothes. Furthermore, it may mean "goods" that are used for producing other goods such as machineries in the factories. For that reason, the meaning of the economic terminology may change from a context to another. Another thing is the collocations which are a combination of two words or more that occur together. So, collocations are classified according to their occurrence in the language. In some cases, they may be translated according to the identical Arabic equivalents but in other cases, there are some English collocations that do not have identical Arabic equivalent collocations (Hatim, B. and Munday, J. 2004). For example, "call money", which means deposits on demand وديعة تحت الطلب' ' و ' Wadiy'zatahttațtlab].

On the other hand, some economic terms are of specific-culture and sometimes have no relation to its individual word even some bilingual dictionaries do not have specific meaning for it. These terms are used metaphorically. For example, "hot money", which means in Arabic as'رأس مال المضاربة' ر'R'as māl almuāḍrba ], also, "crossed cheque", which means cheque that is marked by two parallel lines. This an idiomatic expression can be translated into Arabic language as' شيك مسطر '[Š 'Sُiaykmustttr ], "dribbling offers" , [ [ Dakllkabiyr ] as well as "a window of opportunities" , فرص سانحة ] [ Furaṣsaniḥa ]. Such those expressions can be used metaphorically in the economics but they are rarely occurred. Therefore, translator should be aware when dealing with figurative language because the incorrect choice for the closest equivalence in the target language may distort the whole meaning of the terminology in source language. Moreover, there are some economic terminologies, which are not known in classical Arabic language but have a clear equivalence. For example, "Bank"'بنك '[Bank ]. In addition, synonyms in the economic 
language can be considered as multiple-meanings terms according to the its connection with other words in the text. For example, "stock company" is an idiomatic expression that can be translated into Arabic as شركة مساهمة' 'شكّirkamusāhama ], also, "Stock partnership" that can be translated into Arabic as' شركة تضامنية ' [Širka taāḍmuniya ].

In different situations, people communicate or speak differently, according to the type and goal of activity that mainly, control the language, which they have used. Using the language through communication is considered as a strategy. For that reason, Baker (1992) called this strategy as a language register, which refers to variety of language that language users consider appropriate to a specific situation. In this sense, Sager (1990) distinguished between two registers, the first one is Language for General Purposes (LGP). Whereas, the second, is called Language for Specific Purposes (LSP). Language for Specific Purposes (LSP) is used in specialized contexts usually between experts during communication about a specific object of specific field. Whilst, Language for General Purposes (LGP) is the language which is used every day during general communication between people from diverse backgrounds.

In connection with Language for Specific Purposes (LSP), the translators encounter many problems and ambiguity when they translate topics in social sciences that carry economic terminology. In this respect, the language that used in translation of the terminology may become closer to be an international language. For that reason, Katan (2004:45) points out that "The idea of English as an international language and the use of a standardized international technical language are attempts at making both language and culture technical". Katan adds that the language, which is culture-free is considered as artificial or auxiliary language and needs more practice. This idea connects the terminology with the society's culture.

\section{Cultural dimensions of the economic terminologies}

Some scholars in translation field consider the culture as sub-ordinary factor during translating process. In addition, many of them consider the culture as one of the most important factors related to meaning. They proposed many methods in dealing with those problems. For example, Snell-Hornby (1980: 39) considers culture as "... all society conditional aspect of life". Newmark(1988: 94) points out that culture "have involved linguistic and non-linguistic features". He, also, states "I define culture as a way of life and its manifestations that are peculiar to a community that uses a particular language as its means of expression". Therefore, culture determines how the people speak and how they write and perceive each other. Other authors have considered the translation as transference of one culture into another culture. Some of them go even further and consider the culture as the essence of any translated text.

Culture is classified within lexical features that may affect the meaning during translation. In this regards, translating from culture to culture means first and foremost to bring to the receptors new facts and ideas inherent in the source language culture, to 
broaden their cultural horizons to make them aware that other people may have different customs, symbols and beliefs that other cultures should be respected.

There is no doubt that culture has many features in translation. In this sense, many theoreticians in translation field discussed this topic and each one has his own view. According to (Yowelly and Lataiwish,(2000), the relationship between culture and translation is called "integration" in the sense that the degree of integration of the source text (ST) in the target culture (TC) may vary and may cause serious problems for the translator. In this respect, culture may lead to different types of translation. According to (Yowelly and Lataiwish(2000), translation may preserve only the source culture (SC) and in this case, it is termed "source translation". It may preserve neither the source nor the target culture and here it is called "alienation". Moreover, the absence of culture with no doubt will cause problems of misunderstanding the meaning in source language and therefore, in the target language. In this sense, a lack of culture will affect the meaning and make it weak specially in economic field.

On the other hand, the concept of culture is wide to conclude all aspect of life including economic aspects. In this regard, Economic Commission for Europe Working Group on Cultural Statistics in (UNESCO, 1982: 13) decided that there are three main considerations should govern the designing of a framework for cultural statistics. One of these considerations involves that; framework for cultural statistics must be integrated, including both the social and economic aspects of cultural phenomenon in whole, such as production, distribution consumption of resources and demand for cultural goods and services, which are important in this field. Therefore, each one in the society should have knowledge about it but during translating of the economic terminology, the translators may confront a cross-cultural terms, which are known as universal terms. These terms do not belong to a specific culture and they have a scientific or a technical nature. These terms are not restricted to a specificculture or language and they do not impose serious translation problems for the translator because they will become easy to find out the equivalences in the target language that can be achieved under the condition of mastering a good culture in source language, concerned the topic. For example the world "bank". Such this terminology is worldwide usage in many cultures by the same meaning.

On other side, there are other terms, which are called cultural specific terms. These terms belong to one language. Thus, it is not easy for the translator to find their equivalence in target language. For examples: "Off shore" is a description for the purchases of U.S.A from its alliances, who suffer financial a shortage in their budget. These purchases come as the helpful policy, which aims at helping those countries. This economic term can be translated into our Arabic as-فنشور 'ا [ [ Uffs̄ūr], also the word " Cartel" is a group of firms, which act together to coordinate the decisions in the markets and control prices as they were a single monopoly. This economic term can be translated into Arabic as إتحاد احتكاري -[Etihād ehtikriy]. This type of terminologies is 
called Specific-culture concepts which are specific to the source language (SL) culture.

An equivalence in the economic translation describes the nature and the extent of the relationship between the source language (SL) and target language (TL) text. In this respect, theoreticians in translation field classify the equivalence into several types. Their classification comes according to the problems, which they confront during the translating process. In this sense, Nida (1964) suggests formal and dynamic or functional equivalence. Formal equivalence focuses on the message itself in both form and content. Furthermore, Dynamic equivalence determines the relationship between the receptor and message. This relationship should be the same as the relationship, which exists between the original receptors and the message. According to Koller(1997), the types of equivalence are denotative, connotative, pragmatic, textual, formal and aesthetic equivalence and it will be used in the economic translation. In this regard, Munday (2001) describes these five types of equivalence as follows:

- Denotative equivalence is related to equivalence of the extra linguistic content of a text.

- Connotative equivalence is related to the lexical choices, especially between nearsynonyms.

- Pragmatic equivalence or communicative equivalence is oriented towards the receiver of the text or the message.

- Text-normative equivalence is related to text types, with texts behaving in different ways.

- Formal equivalence is related to the form and aesthetics of the text, includes the individual stylistic features of the source text.

\section{Findings}

This study has revealed that our good knowledge for the nature of the economic language beside the culture at this field can be considered as an essential element in translation of the economic terminologies. These factors help the translator to achieve the best understanding for the economic terms and then the equivalence in the target language. The findings, also, show that the economic terms often have not fixed meaning, especially when they connect with other words in the text. For example, "stock" is a term that can be translated into Arabic language as , مخزون '. [ Makzzūn ] . This term may connect with other words and therefore, it may acquire new meanings as follows:

- "Stock market" is an idiomatic expression in the economics that can be translated into Arabic as' سوق أور اق مالية 'Suwqurāq maliya ].

- "Inventory stock" is an idiomatic expression in the economics that can be translated into Arabic as ' مخزون أخر المدة ' Maknzuwnakniralmuda ].

- The results reveal that good knowledge in source language and the economic culture help the translator to overcome the propositional meaning difficulties. These 
difficulties cause the lack of equivalence in the target language.

The findings, also, reveal that the synonyms in the economic language can be considered as the terms with multiple meanings depending on the context and they create difficulty in translation of the economic term.

- The findings indicate that many strategies can be used while dealing with the economic terms as well as the terms, which have no equivalence in Arabic language. Some of the famous strategies are as follows:

Loan words. For example, "cheque" is a term that can be translated into Arabic as , , شيك [ Šiayk ].

- Modulation. For example, "clearing chamber' is an idiomatic expression that can be translated into Arabic as 'غرفة المقاصة' [ Gurfatalmuqāṣa ].

- Loan word plus explanation. For example, "cartel' is a term that can be translated into Arabic as "الكارتل- إحتكار شركات للسوق [Alkārtil- Eḥtikār širkāt lisuwq].

-Transcription. For example, "agio" is a term that can be translated into Arabic as' [ Ajiyū ], also, "bourgeoisie" is a term that can be translated into Arabic as برجوازية' [Burjwāziya].

- Superordinate. For example, "equipments" is a term that can be translated into Arabic 'التجهيزات' [ 'لوازم' Lwāzim ], also, 'fittings' that can be translated into Arabic as [Attajhizāt].

\section{Recommendations}

- The translator must be familiarized with the elements that affect the meaning of the economic term because the meaning is the main leading cause to failure in achieving the appropriate understanding of any particular term. These elements are the specific nature of the economic language as well as the economic culture.

- The translators must be qualified with the specific features of the economic terms by providing them with specific training courses in the economy, in order to meet the need of translating such this type of terms, to be able to activate his relevant background knowledge in this field.

- The translator should expand his cultural scopes, which improve his ability to achieve the best understanding for the meaning of the economic term.

- The translator should enhance his ability in dealing with the economic terms through many ways as reading the topics in this field, getting involved in training programs or courses and so forth.

- The translator should be familiarized with source and target language of the economic terms to be able to recognize the concept, which does not have equivalence in the target language to be able to deal with it appropriately. 


\section{Conclusion}

We can say that the equivalence in the economic translation takes special attention in translation. Moreover, we should know that it is impossible to find two terms as the same in two languages as English and Arabic. Therefore, the translator may face the problem of non-equivalence while translating the source language message into the target language massage. This is mainly, because of the existence of differences at the cultural and linguistic dimensions. Translators may realize that the economic language term requires different nature. Therefore, culture in this field becomes an urgent need for the translators because of many terms in English may have non-equivalence in Arabic. In this regard, when there is no equivalence or term that directly refers to the source language term, the target language term is mechanically, reproduced with the distortion of grammatical and stylistic patterns. As a result, the formal meaning of the source term is lost in the process of forming a new term in another language. This type of translation is called as "non-equivalence" where the target language term has no equivalence for a word, which occurs in source text. Therefore, translators have to expand their culture by reading in order to catch the nearest equivalence for the existing term that have non-equivalence in the target language.

Many researchers talked about the non-equivalence topic in translation and their views were approximately similar for a number of factors or reasons. Accordingly, nonequivalence may be at the level of word or above it and non-equivalence at word level can occur because of the absence in the target culture of a relevant situational feature for the source language text. Non-equivalence can, also, appear beyond word level, since words do not occur alone in the text but they almost occur on the company of other words. Additionally, non-equivalence beyond word level characterizes notions like metaphors, collocations and idioms. These notions may convey meanings that do not appear clearly from the existing words. In the economic translation the terms that have no-equivalence are specific-culture terms. So, translators need to pay a great attention to such issues in order to get best translation.

\section{References}

1. Baker, M. (1992). In Other Words: A Course Book on Translation. London: Routledge.

2. Cultural Statistics, UNESCO (1982). Economic Commission for Europe Working Group.

3. Economic Dictionary, (Arabic- French -English- German),(1 $1^{\text {st }}$ Ed). (1985). Lebanon: TheArab Institute for Research and Publishing.

4. Hatim, B. and Munday, J. (2004). Translation: An Advanced Resource Book. London and NewYork:Routledge. 
5. Katan, D.(2004 ). Translating Cultures: An Introduction for Translators, Interpreters and Mediators. Manchester: St. Jerome.

6. Koller, W. (1997). The Concept of Equivalence and the Object of Translation Studies. Target, 7 (2), 190-222.

7. Krings, P. (1986). Translation Problems and Translation Strategies of Advanced Germanlearners of French. In J. House, and S. Blum-Kulka (Eds.),Interlingual and Intercultural communication (pp. 263-75). Tubingen: Gunter Narr.

8. Munday, J. (2001). Introducing Translation Studies Theories and Applications, Routledge.

9. Newmark, P. (1988). Textbook of Translation. Oxford: Pergamon Press.

10.Newmark, P. (1991). About translation (Vol. 74). Multilingual matters.

11.Nida, E. A. (1964). Toward a science of translating: with special reference to principles and procedures involved in Bible translating. Brill Archive.

12.Nida, E. A., \& Taber, C. R. (Eds.). (1982). The theory and practice of translation (Vol. 8).Brill Archive.

13.Snell-Hornby, M. (1988). Translation studies: An integrated approach. John Benjamins Publishing.

14.Wehr, H. (1979). A dictionary of modern written Arabic. Otto Harrassowitz Verlag.

15.Wilss, W. (1982). The science of translation: problems and methods (Vol. 180).

16. Yowelly. A. and Lataiwish, M. S. (2000). Principles of translation. Benghazi: Dar Annahda Alarabia. 